\title{
Effect of Antioxidant and Heat Treatment on the Free Fatty Acids Formation of Differently Processed Coconut Oil
}

\author{
Chandi Yalegama*1, Muthumali Sovis ${ }^{2}$ and D. Dissanayake ${ }^{2}$ \\ 1. Coconut Research Institute, Lunuwila 2. University of Colombo \\ *Corresponding author - Coconut Research Institute, Lunuwila, Sri Lanka. \\ Telephone - 94-31-2262007 Fax - 94-31-2257391 \\ Email-cyalegama@yahoo.co.in
}

\begin{abstract}
This study investigated the effect of heat treatment $\left(100^{\circ} \mathrm{C}\right.$ and $\left.150^{\circ} \mathrm{C}\right)$ with or without addition of tocopherol $(0 \mathrm{mg} / \mathrm{L}-300 \mathrm{mg} / \mathrm{L})$ in the formation of free fatty acids in differently processed coconut oil, dry processed virgin coconut oil (DVCO), wet processed virgin coconut oil (WVCO), white coconut oil (WCO), paring coconut oil (PCO) and soya oil. FFA content of all oils stored for a period of 3 months were determined. The results show that WVCO had the lowest FFA content $(0.035 \%)$ followed by DVCO, WCO, Soya and paring oil. The initial FFA content reduced when the respective oils were heated to $100^{\circ} \mathrm{C}$ or $150^{\circ} \mathrm{C}$. This indicates that heat treatment can improve the quality of coconut oil. Addition of tocopherol to DVCO, WVCO and WCO in $100 \mathrm{mg} / \mathrm{L}, 200$ $\mathrm{mg} / \mathrm{L}$ and $300 \mathrm{mg} / \mathrm{L}$ had a significant effect on controlling FFA development of the oil. Addition of tocopherol in $200 \mathrm{mg} / \mathrm{L}$ had significantly lower FFA content in DVCO both with and without heat treatment. WVCO and WCO had lowering effect of FFA due to addition of tocopherol in 200 $\mathrm{mg} / \mathrm{L}$. However it was not significant.
\end{abstract}

Key words : Coconut oil, virgin coconut oil, free fatty acids and tocopherol

\section{INTRODUCTION}

Sri Lankan per capita consumption of coconut oil is about 4 liters (Central Bank report, 2002). Several methods are available for extracting oil from the kernel. Coconut oil is extracted from dried coconut kernels known as copra. Coconut oil is also extracted from the fresh kernel using coconut milk in domestic level.
Among the various types of coconut oil available, virgin coconut oil is a product which is extracted from kernel by using mild heat during oil extraction preventing chemical changes in the coconut kernels and ensuring physical separation of the oil from the kernel. This can be done in two methods. More convenient method is the use of dehydrators to dry kernel at controlled temperature within 3-4 hours taking measures not to undergo chemical or microbial changes 
in the kernel followed by using expellers, which are capable of expelling oil at low temperatures. This is referred to as dry processing of virgin coconut oil. The second method is use of coconut milk which is left for natural or mechanical separation of oil and water. This is referred to as wet processing of virgin coconut oil.

Coconut oil contains $92 \%$ short and medium chain saturated fatty acids. Lauric acid is the major component of fatty acids of coconut oil. White coconut oil and refined, bleached and deodorized (RBD) coconut oil were considered as edible coconut oils until recently. However producing coconut oil in more hygienic and controlled conditions the term "virgin coconut oil" has become innovation to the coconut oil industry. Virgin coconut oil is an improved product with unique features and it is gaining popularity in the world market. Usages of virgin coconut oil are due to its medicinal, cosmetic, cooking and therapeutic properties.

Coconut paring oil or Kurutu oil is another form of coconut oil which is prepared from the pared brown skin or testa of coconut kernel which is available as a by-product in desiccated coconut ( DC ), coconut milk and virgin coconut oil industries. Depending on the time taken to dry pared brown skin, different quality of oil will result. This oil becomes rancid easily and therefore not very good for consumption. Pared brown testa can also be used to prepare edible coconut paring oil if properly processed. According to the iodine value of paring coconut oil it contains more unsaturated fatty acids compared to normal coconut oil (SLS, 1998) and can be used for edible purpose.

Physical and chemical changes take place during the storage of coconut oil. Both free fatty acid formation are peroxide formation are important chemical reaction of edible oils These changes add objectionable odour, taste and palatability of the oil.

This study was undertaken to investigate keeping quality of differently processed coconut oil using heat treatment method with or without addition of tocopherol as an antioxidant. Sri Lanka produces coconut oil in various qualities. It is very important to find out which one has higher keeping quality to improve the process of making coconut oil. Therefore a study was designed to investigate shelf life of differently processed coconut oil, effect of temperature and the addition of antioxidant.

\section{MATERIALS AND METHODS}

\section{Preparation of coconut oil dry processed virgin coconut oil (DVCO)}

Seasoned mature coconuts (seasoned for 3-4 weeks) were dehusked, shells were removed and brown testa peeled off. The kernel was disintegrated mechanically using locally fabricated disintegrator. The disintegrated kernels were dehydrated at $70{ }^{\circ} \mathrm{C}$ until final moisture content is around 3-4\%. On the following day the dehydrated coconut kernels were fed into the virgin coconut oil expeller and oil was expelled at $60{ }^{\circ} \mathrm{C}$. Crude oil was kept for sedimentation and filtered through cotton wool. DVCO was stored in pre-sterilized glass bottles

\section{Wet processed virgin coconut oil (WVCO)}

Virgin coconut oil was extracted directly from coconut milk under controlled temperature. The coconut kernels were grated using an electic grater and coconut milk was extracted with hand squeezing method using water ( $1: 1 \mathrm{w} / \mathrm{w}$ ratio). 
The milk was allowed to settle at $4{ }^{\circ} \mathrm{C}$ for 24 hrs. White layer was separated and solidified at $4{ }^{\circ} \mathrm{C}$. The solidified white mass was transferred into a pan and heated at $100{ }^{\circ} \mathrm{C}$ for $2-2 \frac{1}{2} \mathrm{hr}$, oil layer on the surface was collected, filtered and stored in pre-sterilized glass bottles.

\section{White coconut oil (WCO)}

White coconut oil was purchased from retail outlet in Dankotuwa, Sri Lanka. Commercially available WCO in unpack (bulk) form was used.

\section{Pairing coconut oil (PCO)}

Dehydrated pared brown testa of coconut was obtained from Marawila DC mill, Marawila, Sri Lanka. Oil was extracted using locally available baby expeller (Sri Lankan make). The oil was kept for sedimentation and filtered using cotton wool and stored in pre-sterilized glass bottles.

\section{Soybean oil (SO)}

Soybean oil was purchased from Food City supermarket at Negombo, Sri Lanka Commercially available bottled SO was used.

\section{Heating coconut oil at various temperatures}

Liter of each oil (DVCO, WVCO, WCO, PO and SO) was heated to $100^{\circ} \mathrm{C}$ and $150{ }^{\circ} \mathrm{C}$ and maintained for $1 \mathrm{hr}$. One liter of each oil sample was kept as control without heating. Each oil sample was divided in to four portions $(250 \mathrm{~mL}$ each) and stored in pre - sterilized wide mouth glass bottles.

\section{Addition of $\alpha$ - tocopherol}

The $\alpha$-tocopherol (Sigma Aldrich, USA) was added to DVCO, WVCO and WCO at
$30{ }^{\circ} \mathrm{C}$, heated to $100{ }^{\circ} \mathrm{C}$ and $150{ }^{\circ} \mathrm{C}$ to obtain $0 \mathrm{mg} / \mathrm{L}$ (control), $100 \mathrm{mg} / \mathrm{L}, 200 \mathrm{mg} / \mathrm{L}, 300$ $\mathrm{mg} / \mathrm{L}$ concentrations. Each oil sample was stored at room temperature in pre-sterilized glass bottles.

\section{Determination of Free fatty acids (FFA)}

Free fatty acid content of each oil sample was determined using AOAC (1998). Each analysis was carried out in triplicate.

\section{Statistical Analysis}

Each analysis was carried out in triplicates and mean values and standard deviations were calculated. Mean values of FFA content at $t=0$ were compared with means values of FFA content at each time interval using student tvalue at $95 \%$ confidence interval .

\section{RESULTS AND DISCUSSION}

According to the Table 1 all differently processed coconut oil and soya oil at $30^{\circ} \mathrm{C}$ show significant increase of FFA during storage. 
Table 1: Variation of FFA of differently processed coconut oil and soya oil with storage

\begin{tabular}{cccc}
\hline Duration & \multicolumn{3}{c}{ FFA content $(\%)$ as lauric acid } \\
\cline { 2 - 4 } (weeks) & $\mathbf{3 0}{ }^{\circ} \mathbf{C}$ & $\mathbf{1 0 0}{ }^{\circ} \mathbf{C}$ & $150^{\circ} \mathbf{C}$ \\
\hline DVCO & & \\
0 & $0.041^{\mathrm{a}}$ & $0.039^{\mathrm{a}}$ & $0.063^{\mathrm{a}}$ \\
3 & $0.047^{\mathrm{b}}$ & $0.042^{\mathrm{a}}$ & $0.061^{\mathrm{a}}$ \\
6 & $0.052^{\mathrm{c}}$ & $0.052^{\mathrm{b}}$ & $0.059^{\mathrm{a}}$ \\
9 & $0.060^{\mathrm{c}}$ & $0.057^{\mathrm{b}}$ & $0.059^{\mathrm{a}}$ \\
12 & $0.067^{\mathrm{d}}$ & $0.072^{\mathrm{c}}$ & $0.075^{\mathrm{b}}$ \\
\hline WVCO & & & \\
0 & $0.035^{\mathrm{a}}$ & $0.041^{\mathrm{b}}$ & $0.045^{\mathrm{b}, \mathrm{c}}$ \\
3 & $0.039^{\mathrm{a}}$ & $0.042^{\mathrm{a}}$ & $0.052^{\mathrm{b}}$ \\
6 & $0.044^{\mathrm{b}}$ & $0.049^{\mathrm{b}}$ & $0.052^{\mathrm{b}}$ \\
9 & $0.049^{\mathrm{b}}$ & $0.050^{\mathrm{b}}$ & $0.056^{\mathrm{b}, \mathrm{c}}$ \\
12 & $0.056^{\mathrm{c}}$ & $0.052^{\mathrm{b}}$ & $0.058^{\mathrm{c}, \mathrm{d}}$ \\
\hline
\end{tabular}

\section{WCO}

$\begin{array}{cccc}0 & 0.116^{\mathrm{a}} & 0.093^{\mathrm{a}} & 0.096^{\mathrm{a}} \\ 3 & 0.136^{\mathrm{b}} & 0.133^{\mathrm{b}} & 0.135^{\mathrm{b}} \\ 6 & 0.154^{\mathrm{c}} & 0.142^{\mathrm{c}} & 0.147^{\mathrm{c}} \\ 9 & 0.154^{\mathrm{d}} & 0.147^{\mathrm{d}} & 0.150^{\mathrm{c}} \\ 12 & 0.172^{\mathrm{e}} & 0.155^{\mathrm{e}} & 0.160^{\mathrm{d} 2}\end{array}$

\section{PCO}

$\begin{array}{cccc}0 & 1.28^{\mathrm{a}} & 1.28^{\mathrm{a}} & 1.32^{\mathrm{a}} \\ 3 & 1.36^{\mathrm{b}} & 1.35^{\mathrm{b}} & 1.40^{\mathrm{b}} \\ 6 & 1.45^{\mathrm{c}} & 1.45^{\mathrm{c}} & 1.56^{\mathrm{c}} \\ 9 & 1.60^{\mathrm{d}} & 1.53^{\mathrm{d}} & 1.67^{\mathrm{d}} \\ 12 & 1.70^{\mathrm{e}} & 1.70^{\mathrm{e}} & 1.72^{\mathrm{e}}\end{array}$

\section{SO}

$\begin{array}{cccc}0 & 0.054^{\mathrm{a}} & 0.056^{\mathrm{a}} & 0.062^{\mathrm{a}} \\ 3 & 0.077^{\mathrm{b}} & 0.081^{\mathrm{b}} & 0.084^{\mathrm{b}} \\ 6 & 0.109^{\mathrm{c}} & 0.111^{\mathrm{c}} & 0.099^{\mathrm{c}} \\ 9 & 0.115^{\mathrm{d}} & 0.117^{\mathrm{d}} & 0.121^{\mathrm{d}} \\ 12 & 0.212^{\mathrm{e}} & 0.212^{\mathrm{e}} & 0.243^{\mathrm{e}}\end{array}$

Each value is the mean of triplicate analysis. Means vales at week $0(\mathrm{t}=0)$ were compared with mean values of each time intervals using student t-distribution. Different letter superscripts in each column are significantly different at $\mathrm{p}<0.05$ level. 
Compared to the initial FFA content of the oils at $30{ }^{\circ} \mathrm{C}, 63.4 \%, 60.0 \%, 48.2 \%, 32.8 \%$ and $292 \%$ increase was observed in DVCO, WVCO, WCO, PCO and soya oil respectively at the end of 3 months (Table 01). Therefore soya oil undergoes rapid change of FFA although it is chemically refined. Compared to soya oil which is an unsaturated oil, coconut oil at 30 ${ }^{\circ} \mathrm{C}$ is relatively stable as it shows only $30-65 \%$ increase of FFA compared to $291 \%$ of FFA in soya oil during 3 months of storage.

Effect of heat treatment on FFA formation is given in Table 1. DVCO heated to $100{ }^{\circ} \mathrm{C}$ and $150{ }^{\circ} \mathrm{C}$ increased significantly in $85 \%$ and 20 $\%$ respectively. According to this DVCO at 150 ${ }^{\circ} \mathrm{C}$ is more stable than DVCO heated to $100^{\circ} \mathrm{C}$. FFA content of WVCO heated to $100{ }^{\circ} \mathrm{C}$ and $150{ }^{\circ} \mathrm{C}$ show significant increase compared to FFA content WVCO at $30^{\circ} \mathrm{C}$. However WVCO lower FFA contents compared to corresponding FFA contents of DVCO. According to the results virgin oil (both DVCO and WVCO) is good for frying and cooking purposes as they show lower FFA formation at $100{ }^{\circ} \mathrm{C}-150{ }^{\circ} \mathrm{C}$ temperature range. Therefore food cooked in virgin coconut oil has longer storage time compared to soya oil.

The percentage increases of FFA content of DVCO and WVCO at $30{ }^{\circ} \mathrm{C}$ during 3 months storage were $63 \%$ and $60 \%$ respectively. Therefore both types of virgin oil show similar storage capacities. However, heat treated DVCO and WVCO show different storage capacities (Table 1). FFA content of DVCO heated to 100 ${ }^{\circ} \mathrm{C}$ shows $76 \%$ increase while WVCO heated to $100{ }^{\circ} \mathrm{C}$ shows $49 \%$ increase during 3 months storage. Similar changing pattern of FFA content is observed in DVCO and WVCO heated to 150 ${ }^{\circ} \mathrm{C}$. Therefore WVCO shows higher stability than DVCO at high temperatures.
The reason for lower FFA contents in WVCO may be due to the boiling of coconut milk at $100{ }^{\circ} \mathrm{C}$ for 2.5 hours for separating of the oil layer. This can deactivate lipase enzyme which results in reducing hydrolysis of fat molecules. Bawalan and Chapman (2006) stated that lower grade coconut oil can be purified using boiling coconut oil through steam. Therefore during boiling of coconut milk the initial free fatty acids can evaporate resulting lower free fatty acid content in the oil. In contrast, DVCO is processed below temperatures of $70{ }^{\circ} \mathrm{C}$ and therefore, lipase enzyme can retain in the oil resulting FFA content of DVCO slightly higher than FFA content of WVCO. However both values are far below the maximum allowable limit of FFA for virgin coconut oil of SLS standard which is $0.2 \%$ (SLS standard, 1998). Therefore storage time can be extended further or until it reaches $0.2 \%$.

White coconut oil at $30^{\circ} \mathrm{C}$ has comparatively higher FFA content $(0.116 \%)$ compared to corresponding DVCO and WVCO (Table 1). The reason for the higher FFA value is due to improper way of handling copra. WCO is produced from copra of various categories (stored or contaminated). During storage, copra deteriorates initiating forming of FFA. Therefore high FFA content of WCO manufactured from different grades of copra can be accepted.

The initial FFA content of WCO at $30^{\circ} \mathrm{C}$ decreased in $20 \%$ and $17 \%$ when the WCO is heated at $100{ }^{\circ} \mathrm{C}$ and $150{ }^{\circ} \mathrm{C}$ respectively. This is due to the evaporation of FFA at high temperatures (Bawalan and Chapman, 2006). The FFA content of WCO increased during the storage significantly. The percentage increase of FFA of WCO at $30^{\circ} \mathrm{C}$ is $48 \%$ at the end of 3 months period. The WCO heated to $100{ }^{\circ} \mathrm{C}$ and $150^{\circ} \mathrm{C}$ has significantly lower percentage 
increases of FFA ( $34 \%$ and $38 \%$ ) compared to the FFA content of $\mathrm{WCO}$ at $30^{\circ} \mathrm{C}$. The lesser percentage increase may be due to the low initial FFA and the sterilization of the oil at high temperature. As the maximum allowable FFA content of WCO is $0.8 \%$ (SLS standard, 1998) the WCO can be stored for more than 3 months.

Results in the Table 1 shows that the FFA content of PCO is very high and it exceeds the maximum allowable limit of FFA for edible purpose $(0.8 \%$ maximum -SLS 32:2002). This is because the pared brown testa is not dehydrated immediately after the separation from the white kernel. The brown testa is dehydrated using sunlight or uncontrolled heating systems which take several days for complete dehydration. Due to uncontrolled way of heating formation of FFA occurs in pared brown testa even before the oil is expelled. Therefore initial FFA content of PCO is more than 10 times higher than the FFA of WCO. Paring oil contains higher amount of unsaturated acid content than the white coconut oil does (SLS 32:2002). The contamination of paring due to microbial growth can take place and high moisture content also can promote hydrolytic rancidity due to slow drying process. The results of present study show that paring oil is not edible grade and it has high FFA value and stability of paring oil is very poor compared to white and virgin coconut oil.

Soya oil (SO) is highly unsaturated edible oil. The initial free fatty acid content of refined, bleached and deodorized (RBD) soya oil is very close to the FFA of DVCO. Refining process is done for removal of FFA formed during the process to increase its shelf life. Soya oil has low initial FFA values although it is highly unsaturated oil (Table 1). Formation of free fatty acids in soya oil may be due to hydrolytic rancidity or products formed due to peroxidation. The results in the Table 1 shows that the increase of FFA at high temperatures is in negligible amounts. The increase of FFA content of soya oil during storage is significant at $0.05 \%$ level. At the end of the 3 months the FFA of soya oil increased in $292 \%$. This suggests higher instability of soya oil compared to differently processed coconut oils.

\section{Effect of tocopherol on FFA formation}

The Table 2 shows the effect of tocopherol concentrations on the formation of FFA. The tocopherol added in 100-300 mg/L concentrations has lower FFA content compared to the sample without tocopherol. 
Table 2 : Effect of tocopherol on the formation of FFA in dry processed virgin coconut oil

\begin{tabular}{lccccc}
\hline Tocopherol (mg/L) & \multicolumn{5}{c}{ FFA content (\%) with time (Weeks) } \\
\cline { 2 - 6 } & $\mathbf{0}$ & $\mathbf{3}$ & $\mathbf{6}$ & $\mathbf{9}$ & $\mathbf{1 2}$ \\
\hline DVCO (30 oC) & & & & & \\
$\quad \begin{array}{l}\mathrm{mg} / \mathrm{L} \\
100 \mathrm{mg} / \mathrm{L}\end{array}$ & 0.042 & 0.047 & 0.050 & $0.060^{*}$ & $0.068^{*}$ \\
$200 \mathrm{mg} / \mathrm{L}$ & 0.035 & 0.043 & 0.048 & $0.054^{*}$ & $0.065^{*}$ \\
$300 \mathrm{mg} / \mathrm{L}$ & 0.032 & 0.035 & 0.046 & $0.050^{*}$ & $0.058^{*}$ \\
\hline $\mathbf{D V C O}(\mathbf{1 5 0})$ & 0.037 & 0.035 & 0.050 & $0.056^{*}$ & $0.065^{*}$ \\
$0 \quad \mathrm{mg} / \mathrm{L}$ & & & & & \\
$100 \mathrm{mg} / \mathrm{L}$ & 0.062 & 0.062 & 0.056 & 0.058 & $0.075^{*}$ \\
$200 \mathrm{mg} / \mathrm{L}$ & 0.060 & 0.066 & 0.054 & 0.055 & $0.072^{*}$ \\
$300 \mathrm{mg} / \mathrm{L}$ & 0.056 & 0.058 & 0.050 & 0.052 & $0.065^{*}$ \\
\hline
\end{tabular}

Values are means of three replicates. * indicates the significant changes of FFA compared to the FFA content at $\mathrm{t}=0$ using student $\mathrm{t}$ distribution at $\mathrm{p}<0.05$ level.

Table 3: Effect of tocopherol on the formation of FFA in wet processed virgin coconut oil

\begin{tabular}{lccccc}
\hline $\begin{array}{l}\text { Concentration of tocopherol } \\
(\mathbf{m g} / \mathrm{L})\end{array}$ & $\mathbf{0}$ & $\mathbf{3}$ & $\mathbf{6}$ & $\mathbf{9}$ & $\mathbf{1 2}$ \\
\cline { 2 - 6 } & & & & & \\
\hline WVCO $(30 \mathrm{oC})$ & & & & \\
$\quad 0 \quad \mathrm{mg} / \mathrm{L}$ & 0.035 & 0.037 & 0.042 & $0.047^{*}$ & $0.055^{*}$ \\
$100 \mathrm{mg} / \mathrm{L}$ & 0.033 & 0.036 & $0.042^{*}$ & $0.044^{*}$ & $0.048^{*}$ \\
$200 \mathrm{mg} / \mathrm{L}$ & 0.028 & 0.032 & 0.032 & $0.038^{*}$ & $0.045^{*}$ \\
$300 \mathrm{mg} / \mathrm{L}$ & 0.040 & 0.044 & 0.045 & $0.050^{*}$ & $0.055^{*}$ \\
\hline $\mathrm{WVCO}(150 \mathrm{oC})$ & & & & & \\
$0 \quad \mathrm{mg} / \mathrm{L}$ & 0.045 & 0.052 & 0.051 & $0.055^{*}(22 \%)$ & $0.056^{*}(24 \%)$ \\
$100 \mathrm{mg} / \mathrm{L}$ & 0.040 & 0.042 & 0.051 & $0.054 *(35 \%)$ & $0.053 *(33 \%)$ \\
$200 \mathrm{mg} / \mathrm{L}$ & 0.040 & 0.041 & 0.045 & $0.047(18 \%)$ & $0.051(27 \%)$ \\
$300 \mathrm{mg} / \mathrm{L}$ & 0.047 & 0.051 & 0.057 & $0.058^{*}(23 \%)$ & $0.059 *(26 \%)$ \\
\hline
\end{tabular}

Values are means of three replicates. * indicates the significant changes of FFA compared to the FFA content at $\mathrm{t}=0$ using student $\mathrm{t}$ distribution at $\mathrm{p}<0.05$ level. 
Table 4: Effect of tocopherol on the formation of FFA in white coconut oil

\begin{tabular}{lccccc}
\hline $\begin{array}{l}\text { Concentration of tocopherol } \\
(\mathbf{m g} / \mathrm{L})\end{array}$ & \multicolumn{5}{c}{ Change of FFA (\%) with time (Weeks) } \\
\cline { 2 - 6 } & $\mathbf{0}$ & $\mathbf{3}$ & $\mathbf{6}$ & $\mathbf{9}$ & $\mathbf{1 2}$ \\
\hline $\begin{array}{l}\mathbf{W C O}\left(\mathbf{3 0}{ }^{\circ} \mathbf{C}\right) \\
0 \mathrm{mg} / \mathrm{L}\end{array}$ & 0.118 & $0.135^{*}$ & $0.155^{*}$ & $0.158^{*}(34 \%)$ & $0.170^{*}(44 \%)$ \\
$100 \mathrm{mg} / \mathrm{L}$ & 0.110 & $0.129^{*}$ & $0.138^{*}$ & $0.142 *(29 \%)$ & $0.165^{*}(50 \%)$ \\
$200 \mathrm{mg} / \mathrm{L}$ & 0.105 & 0.110 & $0.125^{*}$ & $0.127^{*}(21 \%)$ & $0.132^{*}(28 \%)$ \\
$300 \mathrm{mg} / \mathrm{L}$ & 0.110 & 0.122 & $0.138^{*}$ & $0.158^{*}(44 \%)$ & $0.165^{*}(50 \%)$ \\
\hline $\mathbf{W C O}\left(\mathbf{1 5 0}{ }^{\circ} \mathbf{C}\right)$ & & & & & \\
$0 \quad \mathrm{mg} / \mathrm{L}$ & 0.098 & $0.135^{*}$ & $0.145^{*}$ & $0.146^{*}(49 \%)$ & $0.160^{*}(63 \%)$ \\
$100 \mathrm{mg} / \mathrm{L}$ & 0.095 & $0.130^{*}$ & $0.142^{*}$ & $0.142^{*}(49 \%)$ & $0.150 *(58 \%)$ \\
$200 \mathrm{mg} / \mathrm{L}$ & 0.090 & $0.118^{*}$ & $0.130^{*}$ & $0.130^{*}(44 \%)$ & $0.140^{*}(56 \%)$ \\
$300 \mathrm{mg} / \mathrm{L}$ & 0.100 & $0.135^{*}$ & $0.145^{*}$ & $0.152^{*}(52 \%)$ & $0.160^{*}(60 \%)$ \\
\hline
\end{tabular}

Values are means of three replicates. * indicates the significant changes of FFA compared to the FFA content at $\mathrm{t}=0$ using student $\mathrm{t}$ distribution at $\mathrm{p}<0.05$ level.

The FFA content of DVCO at $30^{\circ} \mathrm{C}$ with no tocopherol (control sample) increased significantly $(\mathrm{p}<0.05)$ at $9^{\text {th }}$ and $12^{\text {th }}$ week which are $43 \%$ and $62 \%$ compared to the initial FFA of $0.042 \%$ (Table 2). When tocopherol was added to DVCO in 100,200 and $300 \mathrm{mg} / \mathrm{L}$ concentrations the initial FFA content of DVCO reduced from $0.042 \%$ to $0.035 \%, 0.032 \%$ and $0.037 \%$ respectively where $200 \mathrm{mg} / \mathrm{L}$ added sample show significant reduction $(\mathrm{p}<0.05)$. The percentage increase of the FFA content of the DVCO with $0,100,200,300 \mathrm{mg} / \mathrm{L}$ of tocopherol the end of $12^{\text {th }}$ week was $62 \%, 85$ $\%, 81 \%$ and $75 \%$ respectively. The sample with no tocopherol shows slow increase. Therefore DVCO has good stability in storage without adding external tocopherol. This further confirms stability of hygienically prepared DVCO. FFA content of DVCO heated to $150^{\circ} \mathrm{C}$ increased compared to corresponding initial FFA contents (Table 2). The FFA content of control kept for 3 months is similar to the FFA content of DVCO heated to $150^{\circ} \mathrm{C}$.
Table 3 shows that the FFA content of WVCO at $30^{\circ} \mathrm{C}$ without tocopherol (control), WVCO at $30{ }^{\circ} \mathrm{C}$ with tocopherol, and the corresponding WVCOs heated to $150{ }^{\circ} \mathrm{C}$ have lower FFA contents compared to FFA contents of corresponding DVCOs (table 2 and 3). Therefore WVCO has better stability compared to DVCO. However the stability depends on the production temperatures of the WVCO.

According to the results there is and an effect of addition of tocopherol in 100 and 200 $\mathrm{mg} / \mathrm{L}$ levels to WVCO at $30^{\circ} \mathrm{C}$ and at $150^{\circ} \mathrm{C}$. The FFA contents of those samples have come down whereas FFA content increased in the sample with $300 \mathrm{ppm}$ tocopherol compared to the FFA content of the control. Therefore addition of tocopherol is effective in 200 $\mathrm{mg} / \mathrm{L}$ to WVCO without heat treatment. The percentage increase of WVCO with different tocopherol concentrations is given in Table 3 . According to the table WVCO at $30^{\circ} \mathrm{C}$ shows higher percentage increase of FFA compared to the WVCO heated to $150^{\circ} \mathrm{C}$. 
The FFA of all the WCO samples (Control and tocopherol added) are $50 \%$ higher than the FFA contents of corresponding DVCO and WVCO (Table 2,3 and 4). The FFA content of WCO at $30^{\circ} \mathrm{C}$ with no tocopherol (control) has reduce when the tocopherol is added in $100-300 \mathrm{mg} / \mathrm{L}$. However significant reduction is shown only by $200 \mathrm{mg} / \mathrm{L}$. The percentage increase of FFA of control is $44 \%, 50 \%, 28$ $\%$ and $50 \%$ respectively in the presence of $0 \mathrm{mg} / \mathrm{L}, 100 \mathrm{mg} / \mathrm{L}, 200 \mathrm{mg} / \mathrm{L}$ and $300 \mathrm{mg} / \mathrm{L}$ tocopherol at the end of 3 months. WCO with $200 \mathrm{mg} / \mathrm{L}$ has significantly lower FFA values compared to corresponding WCO with 100 and $300 \mathrm{mg} / \mathrm{L}$ of tocopherol. WCO at $150{ }^{\circ} \mathrm{C}$ also shows similar trend of reduction of FFA with the addition of tocopherol in $100-200 \mathrm{mg} / \mathrm{L}$. The percentage increase during storage is $63 \%$, $58 \%, 56 \% 60 \%$ compared to the initial FFA concentration of WCO with $0,100,200$, and $300 \mathrm{mg} / \mathrm{L}$ tocopherol. Therefore there is an effect of addition of tocopherol for WCO.

Senevirathne and Dissanayake (2005) observed $89 \%$ higher acid value and $95 \%$ higher peroxide value in coconut oil made from copra in commercial method compared to home - made coconut oil using coconut milk which is very similar to the WVCO in present study. The present study shows similar finding that WVCO maintains lower FFA content throughout the storage period of 3 months. Frying stability of soya bean oil has been improved by adding 0.05 $\%$ and $0.5 \%$ citric acid (Werner and Gehring, 2009). According to them, lower level (0.05\%) of citric acid had higher antioxidant capacity. Our study also shows improvement of storage with the addition of $200 \mathrm{mg} / \mathrm{L}$ compared to 300 $\mathrm{mg} / \mathrm{L}$.

Mohommed Ali et al. (2011) observed significant increase of FFA of ground nut oil during storage time of 96 days. They further stated that by replacing $30 \%$ of ground nut with palm olein the increase of FFA was slower indicating that saturated oils are more stable than unsaturated fatty acids. Coconut oil is more saturated and therefore more stable (WFLO, 2008). Butylated hydroxi anisole, butylated hydroxy toluene, propyl gallate and tocopherol have been used to slow down oxidation of fats and oil (Sherwin, 1972). Addition of antioxidants cannot stop rancidity completely. The effectiveness lies only in slowing down the rate of oxidation and the activity varies with the anti-oxidant combination and with the food product to be protected (WFLO, 2008).

\section{CONCLUSION}

Virgin coconut oil produced through wet and dry process showed lower FFA content compared to white coconut oil which is produced using copra. WVCO had the lowest FFA content during storage of 3 months followed by DVCO. Addition of $200 \mathrm{mg} / \mathrm{L}$ improved the shelf life of coconut oil by keeping FFA content in a lower level. Coconut oil produced from brown testa of coconut (PCO) is not in acceptable level of FFA and improvements to the method of producing PCO should be done to achieve edible quality 


\section{REFERENCES}

Association of official chemists. Official methods of analysis, $A O A C, 1985$ Bawalan D. D and Chapman K. R. (2006). Virgin coconut oil - Production manual for micro and village scale processing. FAO regional office for Asia and Pacific, Bankok; Food and Agriculture Organization of United Nations.

Mohammed Ali D.O., Ahmed A.H.R. and Mohammed B.E. (2011). Improvements of the quality and storage stability of the Sudanase ground nut oil. Pakistan J of Nutri. 10(2): 159-161 Report of the Central Bank, Sri Lanka, 2002

Senerviratne K.N. and Dissanayake D.M.S. (2005). Effect of method of extraction on the quality of coconut oil. J. Sci. Uni. Kelaniya. 2:63 -72.

Sherwin E. R. (1972). Antioxidants for food fats and oils. J. Amer Oil Chemists 'Soc, 49(8): 468472 SLS 32:2002 Specification of coconut oil. Sri Lanka Standard, Sri Lanka

Werner K. and Gehring M.M. (2009). High temperature natural antioxidants improves soy oil for frying. J. of Fd Sci, 74(6): 500-506

World Food Logistic Organization (WFLO). Commodity storage manual (2008) 